\title{
Risiko Akad dalam Pembiayaan Murabahah pada BMT di Yogyakarta (dari Teori ke Terapan)
}

Oleh: Asmi Nur Siwi Kusmiyati*

\begin{abstract}
This research aim to know the practice of murabahah financing, any kind of risk which is related to murabahah financing, how to manage the risk of murabahah financing, and how is perpective of Moslem law to practice of murabahah financing at BMT in Yogyakarta. This research done by field research by using desain qualitative. In this research, its data collecting by use the documentation and interview technique. As for location becoming this research is: BMT Dana Insani, BMT Amratani Sejahtera, and BMT Bina Ihsanul Fikri (BIF) Nitikan. Result of this research indicate that: (1) practice of murabahah financing at BMT used for the purchasing of consumer goods I capital goods which is payment in instalment or fall due; (2) not all risk of murabahah financing have been experienced by third BMT, BMT Dana Insani have never experienced of the risk which is related to object and risk which is related to member while BMT BIF Nitikan have never experienced of the risk which is related to just object; (3) third BMT have different way of each other in managing risk which is related to murabahah financing; and (4) most concept and execution of murabahah financing at third BMT have as according to principles syariah.
\end{abstract}

Keywords: risiko, akad, murabahah, BMT

* Penulis adalah alumni Program Studi Ekonomi Islam FIAI UII

Vol. I, No. 1, Juli 2007 


\section{Pendahuluan}

Dikeluarkannya Undang-Undang No.10 Thn 1998 tentang Perbankan dan dikeluarkannya Fatwa Bunga Bank Haram dari MUI Tahun 2003 menyebabkan banyak bank yang menjalankan prinsip syariah. ${ }^{1}$

Seiring dengan hal tersebut di atas, Lembaga Keuangan Syariah yang ruang lingkupnya mikro yaitu Baitul Maal wal Tamwil (BMT) juga semakin menunjukkan eksistensinya. Seperti halnya bank syariah, kegiatan BMT adalah melakukan penghimpunan (prinsip wadiah dan mudharabah) dan penyaluran dana (prinsip bagi hasil, jual beli dan ijarah) kepada masyarakat.

Penyaluran dana dengan prinsip jual beli dilakukan dengan akad murabahah, salam, ataupun istishna. Penyaluran dana dengan prinsip jual beli yang paling dominan adalah murabahah. Berdasarkan data statistik perbankan syariah Direktorat Perbankan Syariah Bank Indonesia pada awal tahun 2004, jual beli murabahah menunjukkan posisi lebih dari $50 \%$.

Menurut Choudury, dominannya pembiayaan murabahah terjadi karena pembiayaan ini cenderung memiliki risiko yang lebih kecil dan lebih mengamankan bagi shareholder. ${ }^{2}$

Pendapat yang dikemukakan Choudury di atas secara implisit menunjukkan bahwa walaupun pembiayaan murabahah begitu mendominasi praktek pembiayaan perbankan syariah, namun tetap ada risiko-risiko yang menyertainya. Adanya risiko pada pembiayaan murabahah inilah yang menimbulkan keingintahuan peneliti mengkaji lebih dalam tentang praktek pembiayaan murabahah yang selama ini begitu dominan pada perbankan syari'ah.

Adapun tujuan dari penelitian ini adalah :

A. Mengetahui praktek pembiayaan murabahah pada BMT di Yogyakarta.

B. Mengetahui risiko-risiko yang terkait dengan pembiayaan murabahah pada BMT di Yogyakarta.

C. Mengetahui bagaimana cara BMT di Yogyakarta dalam mengelola risiko yang terkait dengan pembiayaan murabahah.

D. Mengetahui bagaimana perspektif syariah terhadap praktek pembiayaan murabahah pada BMT di Yogyakarta.

\section{Pengertian Murabahah}

Murabahah adalah penjualan dengan harga pembelian barang berikut

${ }^{1}$ Wiroso (2005), Jual Beli Murabahah, (Yogyakarta : UII Press), hal. 1.

2 Sumiyanto (2004), "Problem Transaksi Model Mudarabah dalam Lembaga Keuangan Syariah Studi Kasus LKS BMT-BMT di Yogjakarta”, Tesis MSI UII (tidak dipublikasikan). 
untung yang diketahui. ${ }^{3}$ Dalam pengertian lain murabahah adalah akad jual beli barang dengan menyatakan harga perolehan dan keuntungan (margin) yang disepakati oleh penjual dan pembeli ${ }^{4}$

\section{Landasan Syariah}

Dalam fatwa Nomor 04/DSN-MUI/IV/2000 Tanggal 1 April 2000 tentang Murabahah, sebagai landasan syariah transaksi murabahah adalah sebagai berikut: ${ }^{5}$

A. Al-Qur'an : Al-Baqarah [2]:275.

B. Al-Hadits : Hadis Nabi dari Abu Said al-Khudri: Dari Abu Said Al-Khudri bahwa Rasulullah SAW bersabda, "Sesungguhnya jual beli itu harus dilakukan suka sama suka."(H.R. al-Baihaqi dan Ibnu Majah, dan dinilai shahih oleh Ibnu Hibban).

C. Ijma' : (Ibnu Rusyd, Bidāyah al-Mujtahid, II/161; al-Kasani, Badā'i as-Sanā'i V/220-222).

D. Kaidah Fikih : "Pada dasarnya, semua bentuk muamalah boleh dilakukan kecuali ada dalil yang mengharamkannya".

\section{Jenis Murabahah ${ }^{6}$}

Murabahah dapat dibedakan menjadi dua macam,yaitu : (1) Murabahah tanpa pesanan dan (2) Murabahah berdasarkan pesanan.

Murabahah berdasarkan pesanan dapat dibedakan menjadi murabahah berdasarkan pesanan yang bersifat mengikat dan murabahah berdasarkan pesanan yang bersifat tidak mengikat. Sedangkan jika dilihat cara pembayarannya, maka murabahah dapat dilakukan dengan cara tunai atau dengan pembayaran tangguh.

\section{Ketentuan Umum Murabahah}
A. Jaminan dalam Murabahah ${ }^{7}$
B. Uang Muka
C. Sanksi / Denda

\footnotetext{
${ }^{3}$ Sayyid Sabiq (1988), Fikih Sunnah 12, (Bandung : PT Al-Ma'Arif), hal. 82.

${ }^{4}$ Adiwarman Karim (2003), Bank Islam Analisis Fiqih dan Keuangan, (Jakarta: IIIT Indonesia), hal. 161.

${ }^{5}$ Majelis Ulama Indonesia (2003), Himpunan Fatwa Dewan Syariah Nasional edisi kedua, (Jakarta : MUI), hal. 22-25.

${ }^{6}$ Wiroso, Op cit, hal. 37-38.

${ }^{7}$ M. Syafi'i Antonio (2001), Bank Syariah dari Teori ke Praktik, (Jakarta : Gema Insani), hal. 105.
} 


\section{Aplikasi Murabahah}

Berikut ini adalah beberapa contoh transaksi murabahah dalam praktik :

A. Pengadaan Barang, misalnya kebutuhan sepeda motor untuk pegawai.

B. Persediaan Modal Kerja (modal kerja barang), dilakukan dengan transaksi sekali putus, bukan sekali akad dengan pembelian berulang-ulang. ${ }^{8}$

\section{Risiko dalam Murabahah}

Risiko dalam pembiayaan murabahah diantaranya adalah :'

A. Risiko yang terkait dengan barang

B. Risiko yang terkait dengan klien (nasabah)

C. Risiko yang terkait dengan pembayaran

\section{Metode Penelitian}

\section{A. Jenis Penelitian dan Pendekatan}

Penelitian yang dilakukan ini adalah penelitian lapangan (field research) dengan menggunakan desain kualitatif. Objek yang menjadi sasaran penelitian adalah risiko akad dalam pembiayaan murabahah secara konsep dan aplikasi pada BMT-BMT di Yogyakarta. Penelitian ini menggunakan pendekatan deskriptifanalitis untuk mengetahui landasan konseptual dan aplikatif risiko akad dalam murabahah pada BMT-BMT di Yogyakarta.

\section{B. Teknik Pengumpulan Data}

Dalam penelitian ini pengumpulan datanya menggunakan teknik dokumentasi dan wawancara.

\section{Populasi dan Sampel}

Dalam penelitian ini populasinya adalah BMT-BMT yang tergabung dalam suatu kesatuan PUSKOPSYAH "BMT MITRA NUGRAHA" DIY yang terdiri dari 89 BMT anggota.

Pengambilan sampel dilakukan dengan cara purposive random sampling (pengambilan sampel secara acak dan dengan pertimbangan), yaitu dari 89 BMT

${ }^{8}$ Wiroso, Op cit, hal. 56-57.

${ }_{9}$ Muhammad (2005), Manajemen Pembiayaan Bank Syariah, (Yogyakarta : UPP AMP YKPN), hal. 128-130. 
yang ada diambil secara proporsional berdasarkan aset yang dikelola oleh masingmasing BMT. Aset dari setiap BMT dikelompokkan dalam tiga kategori, yaitu besar (asetnya lebih dari satu milyar rupiah) terdapat $22 \mathrm{BMT}$; sedang (asetnya antara 500juta sampai dengan satu milyar rupiah) terdapat 16 BMT ; dan kecil (asetnya kurang dari 500juta rupiah) terdapat $51 \mathrm{BMT}^{10}$ Dari ketiga kategori ini diambil sampel secara acak (masing-masing kategori satu sampel).

\section{Lokasi dan Waktu penelitian}

Penelitian dilakukan pada BMT-BMT anggota Pusat Koperasi Syariah (PUSKOPSYAH) 11 "BMT MITRA NUGRAHA" DIY, yaitu : BMT Dana Insani, BMT Amratani Sejahtera, dan BMT Bina Ihsanul Fikri (BIF) Nitikan. Penelitian ini dilakukan antara bulan Oktober 2006 - Maret 2007.

\section{E. Pengolahan Data}

Data-data yang diperoleh diolah dengan langkah-langkah sebagai berikut : Pertama, mendeskripsikan kemudian mengklasifikasikan berdasarkan kesamaan praktek murabahah pada BMT di Jogja. Kedua, mendeskripsikan kemudian mengklasifikasikan berdasarkan kesamaan risiko murabahah pada BMT di Jogja. Ketiga, mendeskripsikan kemudian mengklasifikasikan berdasarkan kesamaan manajemen risiko pada BMT di Jogja. Keempat, melakukan penilaian berdasarkan konsep normatif murabahah.

\section{Hasil Penelitian}

\section{A. Prosedur Pengajuan Pembiayaan Murabahah}

Bahwa untuk mengajukan pembiayaan di BMT Dana Insani dan BMT Amratani Sejahtera, syaratnya adalah telah menjadi anggota (memiliki rekening simpanan), sedangkan di BMT BIF Nitikan, pengajuan pembiayaan dapat dilakukan oleh anggota atau calon anggota.

BMT Dana Insani dan BMT Amratani Sejahtera melakukan analisis kelayakan dengan metode 5C. Sedangkan BMT BIF Nitikan analisa kelayakannya tidak hanya menggunakan 5C tetapi juga 4P.

Ketiga BMT mensyaratkan adanya agunan berupa surat berharga. Namun

10 Wawancara dengan Eddy Nofianto (Manajer Pusat Koperasi Syariah (PUSKOPSYAH)) pada 8 Januari 2007, di kantor BMT MITRA NUGRAHA DIY.

${ }^{11}$ Menurut Eddy Nofianto (manajer PUSKOPSYAH), PUSKOPSYAH merupakan koperasi syariah atau BMT primer yang mewadahi BMT-BMT di Jogja yang masuk dalam anggotanya. 
di BMT Dana Insani agunannya juga dapat berupa barang tunjukan atau kelayakan usaha. Sedangkan pada BMT Amratani Sejahtera agunannya juga bukan hanya berupa surat berharga tetapi dapat berbentuk kelayakan usaha.

\section{B. Penentuan Jenis Akad}

Penentuan jenis akad pembiayaan murabahah pada ke tiga BMT dilakukan dengan terlebih dahulu menanyakan tentang tujuan penggunaan dana tersebut. Jika anggota mengajukan pembiayaan untuk membeli barang maka dapat menggunakan akad murabahah.

\section{Penentuan Jangka Waktu}

Penentuan jangka waktu pembiayaan murabahah pada ke tiga BMT dilakukan berdasarkan kesepakatan dengan anggota. Akan tetapi, pada BMT Amratani Sejahtera dan BMT BIF Nitikan terdapat batas jangka waktu maksimal yaitu selama satu tahun.

\section{Penentuan Margin}

Penentuan margin pembiayaan murabahah di BMT Dana Insani selama ini masih berpatokan pada besarnya biaya operasional (minimal sebesar $2 \%$ dari jumlah pembiayaan). Setelah pihak BMT menentukan besarnya margin pembiayaan murabahah, anggota masih bisa menawarnya sehingga margin yang ditetapkan merupakan hasil kesepakatan kedua belah pihak.

Penentuan margin pembiayaan murabahah di BMT Amratani Sejahtera dihitung dengan menggunakan rumus : ${ }^{13} \mathrm{Mp}=(\mathrm{A}-\mathrm{Um}) \mathrm{x} \mathrm{G} / 1 \mathrm{jt} \times \mathrm{T}$

di mana $\mathrm{A}=$ harga barang, $\mathrm{G}=$ proyeksi pendapatan $\mathrm{BMT} /$ bulan (margin yang diharapkan BMT 20.000,- s/d 25.000 / 1 juta), $\mathrm{T}=$ jangka waktu, $\mathrm{Mp}=$ margin / mark up pembiayaan, dan Um = uang muka / urbun.

Sedangkan pada BMT BIF Nitikan, penentuan margin pembiayaan murabahah dilakukan dengan menghitung biaya-biaya yang terkandung dari aset yang dimiliki BMT. Rumus yang digunakan : Biaya operasional/Asset x 100\%

Pihak BMT BIF Nitikan menentukan besarnya margin berkisar antara 2,5-3\%. Margin yang ditentukan oleh BMT masih bisa ditawar oleh anggota sehingga margin yang ditetapkan merupakan kesepakatan kedua belah pihak. ${ }^{14}$

12 Wawancara dengan Yuli Istianto (manajer BMT Dana Insani) pada 9 Februari 2007, di kantor BMT Dana Insani DIY.

${ }^{13}$ Wawancara dengan Eni Arvianti (Manajer Dept. PSDM BMT Amratani) pada 20 Februari 2007, di kantor BMT Amratani Utama DIY.

14 Wawancara dengan Supriyadi (manajer BMT BIF Nitikan) pada 9 Februari 


\section{E. Risiko Pembiayaan Murabahah yang Pernah Dihadapi}

Pada BMT Dana Insani dan BMT BIF Nitikan sering menghadapi risiko penyalahgunaan dana. Sedangkan pada BMT Amratani, risiko yang sering dihadapi adalah jika tidak dapat membelikan barang yang dibutuhkan oleh anggota sehingga harus mewakilkan kepada anggota tersebut untuk membeli barangnya sendiri.

Pada BMT Dana Insani dan BMT BIF Nitikan selama ini belum ada risiko yang terkait dengan obyek murabahah, sedangkan pada BMT Amratani Sejahtera adalah tidak semua jenis barang dapat dibelikan oleh pihak BMT dan apabila pembelian tersebut diwakilkan kepada anggota, BMT tidak dapat melakukan pengecekan secara detail terhadap barang tersebut.

Berkaitan dengan risiko pembayaran, ketiga BMT pernah mengalami pembayaran angsuran yang kurang lancar (realisasi pembayaran tidak sesuai dengan yang telah direncanakan) sehingga akan berpotensi tidak bisa melunasi angsuran.

Risiko yang terkait dengan anggota selama ini belum pernah dihadapi oleh BMT dana Insani, sedangkan pada BMT BIF Nitikan berupa pembatalan akad dan pada BMT Amratani Sejahtera berupa penundaan pembiayaan

\section{F. Monitoring Risiko}

Kegiatan dalam rangka monitoring risiko pada BMT dilakukan dengan cara sebagai berikut :

1. Pada BMT Dana Insani dan BMT Amratani Sejahtera ada pemantauan terhadap rekening anggota sedangkan pada BMT BIF Nitikan tidak ada pemantauan terhadap rekening anggota;

2. pemantauan pelunasan angsuran dilakukan oleh ketiga BMT;

3. ketiga BMT melakukan kunjungan ke tempat anggota, namun pada BMT Amratani Sejahtera kunjungan tersebut hanya dilakukan pada awal proses pembiayaan sedangkan pada BMT Dana Insani dan BIF Nitikan kunjungan tidak hanya di awal pembiayaan tetapi juga secara berkala.

\section{G. Mengelola Risiko Murabahah}

Untuk mengelola risiko yang terkait dengan barang, BMT Dana Insani dan BMT BIF Nitikan mewakilkan kepada anggota untuk membeli barangnya sendiri. Sementara itu, BMT Amratani Sejahtera akan memberikan diskon (mengurangi margin) kepada anggota supaya anggota tetap jadi membeli barang tersebut.

Untuk mengelola risiko yang terkait dengan pembayaran, ketiga BMT

2007, di kantor BMT BIF Nitikan DIY. 
mensyaratkan adanya barang jaminan, namun pada BMT Amratani Sejahtera jaminannya dapat berupa simpanan.

Untuk mengelola risiko yang terkait dengan anggota, BMT BIF Nitikan dan BMT Amratani Sejahtera mensyaratkan adanya uang muka. Uang muka tersebut berupa 30\% dana dari harga barang yang akan dibeli (pada BMT BIF Nitikan) atau dapat berupa simpanan (pada BMT Amratani Sejahtera). Sementara itu, pada BMT Dana Insani tidak mensyaratkan adanya uang muka, namun jika barangnya dibelikan oleh pihak BMT maka akan diusahakan sesuai dengan spesifikasi yang diminta supaya tidak terjadi penolakan dari anggota.

\section{H. Mengatasi Pembiayaan Bermasalah}

BMT Dana Insani akan mengatasi pembiayaan bermasalah dengan melakukan penagihan secara efektif dan rutin, maksudnya adalah terencana dan terjadwal sampai habis jangka waktu pembiayaannya. Selain itu, petugas BMT juga akan melakukan kontrol atau pengawasan, pengecekan dan penanganan yang lebih intensif bagi pembiayaan yang bermasalah tersebut. Jika sampai habis jangka waktunya namun anggota belum melunasi pembayaran maka pihak BMT akan memberikan surat peringatan sebanyak tiga kali. Pada surat ketiga, intinya adalah menanyakan kesanggupan anggota untuk menyelesaikan angsurannya. Jika anggota menyatakan tidak sanggup untuk membayar maka barang jaminan akan dilelang. ${ }^{15}$

Pada BMT Amratani Sejahtera, penanganan pembiayaan bermasalah dengan salah satu atau beberapa cara berikut : resceduling, restructuring, kombinasi 2R (resceduling dan restructuring), dan eksekusi. Resceduling dilakukan dengan cara menjadwal ulang seluruh / sebagian kewajiban anggota (misal : jangka waktu dirubah dengan cara diperpanjang, jumlah angsuran dirubah, margin dirubah dengan cara dikurangi atau pemberian discount, dll). Sedangkan restucturing dilakukan dengan merubah komposisi pembiayaan. Tindakan akhir setelah semua cara tidak berhasil adalah dengan eksekusi, yaitu dengan menyita dan melelang barang jaminan untuk menutup kewajiban anggota.

Pada BMT BIF Nitikan, pembiayaan yang diindikasikan bermasalah akan dideteksi melalui catatan monitoring angsuran. Kemudian dilakukan analisa dan penggolongan pembiayaan untuk memperoleh kepastian kondisi pembiayaan tersebut. Analisa ini harus ditindaklanjuti dengan survey lapangan untuk mengetahui penyebab keterlambatan membayar. Hasil analisa dan survey digunakan untuk menentukan langkah-langkah penanganan yang menghasilkan dua keputusan : 1. pendampingan (jika keterlambatan membayar bukan karena kesengajaan ) dan dilanjutkan dengan restrukturisasi / resceduling sesuai dengan kemampuan peminjam, 2. penagihan, jika peminjam mampu tapi tidak mau

15 Wawancara dengan Yuli Istianto, Op cit, pada 9 \& 26 Februari 2007. 
melunasi hutangnya. Keputusan tersebut ditindaklanjuti dengan pembuatan surat teguran dan surat peringatan. Jika surat teguran tidak mendapat hasil, dilanjutkan dengan surat peringatan atau penagihan I dan II. Dan jika surat penagihan ini tidak diindahkan dan tidak membuahkan hasil, maka barang jaminan akan dieksekusi. ${ }^{16}$

\section{Pembahasan}

\section{A. Penentuan Akad}

Ketiga BMT menentukan akad pembiayaan dengan terlebih dahulu menanyakan tujuan dari penggunaan dana tersebut. Pada BMT Dana Insani, jika anggota mengajukan pembiayaan untuk membeli barang (termasuk pembelian barang dagangan) maka pihak BMT akan menggunakan akad murabahah. Pada BMT BIF Nitikan, anggota biasanya mengajukan pembiayaan murabahah untuk keperluan : (1) menambah modal untuk membeli barang dagangan, (2) membeli kendaraan (misal : sepeda motor) untuk memperlancar usaha, (3)membeli barang konsumsi. Sedangkan pada BMT Amratani Sejahtera, jika anggota mengajukan pembiayaan untuk membeli sesuatu maka dapat menggunakan akad murabahah, namun untuk pembiayaan tambah modal bagi pedagang yang digunakan adalah akad musyarakah.

Menurut Syafi'i Antonio, dalam perdagangan, karena umumnya ada perputaran dana, nasabah dapat mengajukan pembiayaan mudharabah. Bank dan nasabah dapat berbagi hasil / keuntungan dengan memperkirakan perputaran rata-rata omzet pada tiap bulannya. ${ }^{17}$

Berdasarkan pendapat Syafi'i di atas, akan lebih sesuai jika pihak BMT menggunakan akad mudharabah ketika memberikan pembiayaan tambah modal kepada anggotanya. Namun demikian menurut pengurus BMT Dana Insani, penggunaan akad mudharabah pada BMT sulit direalisasikan karena yang menjadi segmennya adalah masyarakat kecil yang minim pendidikan sehingga lebih mudah jika menggunakan akad murabahah ${ }^{18}$.

\section{B. Adanya Agunan}

Sesuai dengan prosedur akad pembiayaan murabahah pada ketiga BMT di atas, pada setiap pembiayaan disyaratkan adanya agunan sebagai barang jaminan. Menggunakan agunan dalam hutang, menurut Qur'an (QS [2]:282)

${ }^{16}$ BMT BIF Group (tt), Sistem \& Prosedur Pembiayaan, (tidak dipublikasikan).

${ }^{17}$ M. Syafi'i Antonio (2001), Bank Syariah dari Teori ke Praktik, (Jakarta : Gema Insani), hal. 171.

${ }^{18}$ Wawancara dengan Tri Martiwi, Op cit. 
dan Sunnah, tidak dengan sendirinya tercela. Qur'an memerintahkan Muslim menulis kewajiban mereka dan jika perlu menggunakan agunan untuk hutang ${ }^{19}$. Nabi dalam beberapa kesempatan memberikan kepada kreditor dengan agunan untuk hutang. Agunan adalah metode menjamin hak kreditor tidak dibayar, dan menghindari "makan hak orang lain tanpa ijin"20. Namun demikian, menuntut agunan dilihat oleh pendukung perbankan Islam sebagai kendala arus keuangan bank kepada para pengusaha yang relatif berpendapatan rendah. Bank-bank Islam cenderung mengkritik bank-bank tradisional karena cenderung "orientasi agunan." ${ }^{21}$

\section{Pengadaan Barang}

Pada BMT Dana Insani dan BMT BIF Nitikan, dalam akadnya disebutkan bahwa pembelian obyek murabahah diwakilkan kepada anggota. Hal ini menunjukkan bahwa dalam transaksi murabahah tersebut pihak BMT menyerahkan uang kepada nasabah (bukan barang) dengan alasan BMT memberikan kuasa kepada anggota untuk membeli barangnya sendiri. Hal ini merupakan salah satu alasan masyarakat yang mengatakan bank syariah / BMT tidak ada bedanya dengan bank konvensional. Sementara itu, pada BMT Amratani Sejahtera pembelian barangnya diusahakan oleh pihak BMT.

Salah satu ketentuan dasar penjualan adalah barangnya harus dimiliki oleh penjual ketika penjualan tersebut berlangsung. Ketentuan ini juga berlaku dalam penjualan dengan cara murabahah. ${ }^{22}$

Menjual barang yang tidak dimiliki adalah tindakan yang dilarang syariah karena termasuk bai al-fudüli. Para ulama syariah terdahulu telah memberikan alasan secara rinci mengenai pelarangan tersebut. Akan tetapi, beberapa ulama syariah modern menunjukkan bahwa konteks jual beli murabahah jenis ini di mana "belum ada barang" berbeda dengan "menjual tanpa kepemilikan barang." 23

Apabila diperhatikan ketentuan fatwa Dewan Syariah Nasional No.4/DSNMUI/IV/2000 Tanggal 1 April 2000 tentang Murabahah, ketentuan pertama, butir 9 disebutkan bahwa "Jika bank hendak mewakilkan kepada nasabah untuk membeli barang dari pihak ketiga, akad jual beli murabahah harus dilakukan

${ }^{19}$ Al-Qur'an $2: 282$.

${ }^{20}$ Al-Qur'an 2 : 188; 4: 161; 9: 34.

${ }^{21}$ Abdullah Saeed (2004), Islamic Banking and Interest A Study of The Prohibition of Riba and its Contemporary Interpretation, Muhammad Ufuqul Mubin, dkk. (terj.), Bank Islam dan Bunga Studi Kritis Larangan Riba dan Interpretasi Kontemporer, (Yogyakarta : Pustaka Pelajar), hal.155.

${ }^{22}$ http : //www.accountancy.com.pk/docs/islam_murabahah.pdf, diakses pada 9 April 2007.

${ }^{23}$ M. Syafi'i Antonio, Op cit, hal. 104. 
setelah barang dibeli, jadi secara prinsip barang tersebut menjadi milik bank". Dari ketentuan tersebut jelas bahwa akad murabahah dapat dilakukan jika barang tersebut secara prinsip telah menjadi milik bank jadi harus ada barangnya dahulu baru dilakukan akad murabahah, tidak diperkenankan melakukan akad murabahah jika tidak ada barangnya. ${ }^{24}$

\section{Uang muka}

Pada BMT Amratani Sejahtera karena pihak BMT yang mengusahakan untuk membeli barang murabahah maka disyaratkan adanya uang muka yang dapat diambil dari simpanan anggota yang mengajukan pembiayaan. Berbeda dengan BMT Amratani Sejahtera, uang muka tidak disyaratkan dalam transaksi murabahah di BMT Dana Insani karena pembelian barangnya diwakilkan kepada anggota. Sementara itu pada BMT BIF Nitikan, sebagian dana untuk pembelian barang dapat berasal dari anggota yaitu sebesar $30 \%$ dari harga pembelian barang sehingga pihak BMT tinggal menambahi sisanya.

Pedoman Akuntansi Perbankan Syariah Indonesia menjelaskan bahwa uang muka harus dibayarkan oleh nasabah kepada Bank Syariah, bukan kepada pemasok (PAPSI,2003). Jadi pembayaran terlebih dahulu kepada pemasok, yang lazim disebut dengan pendanaan sendiri (selffinancing) tidak dapat dikategorikan sebagai uang muka, bahkan banyak yang berpendapat barang yang dibeli dengan dana sebagian dari nasabah tersebut tidak sesuai dengan ketentuan yang tercantum dalam Fatwa DSN Nomor 4/DSN-MUI/IV/2000 ketentuan pertama butir 4 yaitu : "Bank membeli barang yang diperlukan nasabah atas nama bank sendiri,dan pembelian ini harus sah dan bebas riba". ${ }^{25}$

Menurut Syafi'i Antonio, dalam transaksi jual beli murabahah, pembeli (pihak BMT) dibolehkan meminta pemesan (anggota) membayar uang muka atau tanda jadi saat menandatangani kesepakatan awal pemesanan. Uang muka adalah jumlah yang dibayar oleh pemesan yang menunjukkan bahwa ia bersungguhsungguh atas pesanannya tersebut. Bila kemudian pemesan menolak untuk membeli aset tersebut, biaya riil pembeli harus dibayar dari uang muka. Bila nilai uang muka tersebut lebih sedikit dari kerugian yang harus ditanggung pembeli, pembeli dapat minta kembali sisa kerugiannya kepada pemesan. ${ }^{26}$

\section{E. Sanksi / denda}

Menurut Syafi'i Antonio, seorang nasabah yang mempunyai kemampuan ekonomis dilarang menunda penyelesaian utangnya dalam al-muräbahah.

\footnotetext{
${ }^{24}$ Wiroso (2005), Jual Beli Murabahah, (Yogyakarta : UII Press), hal. 68.

${ }^{25}$ Ibid, hal. 101.

${ }^{26}$ M. Syafi'i Antonio, Op cit, hal. 104.
} 
Dalam bank Islam, debitur hendaknya diberikan waktu untuk membayar jika ia tidak mampu membayar menurut perintah Qur'an, “jika debitur mengalami kesulitan, maka diberikan kelonggaran sampai ia mengalami kemudahan." 27

Di dalam praktiknya, bank-bank Islam dengan dukungan Dewan Syariah mereka, telah mempersempit makna perintah al-Qur'an tersebut. Penerapan perintah tersebut secara umum, menurut bank-bank Islam, adalah celah potensial bagi para debitur mereka yang mungkin lalai untuk melunasi hutang mereka padahal mereka mampu melunasinya. Untuk menutup penyalahgunaan celah potensial ini, Dewan Syari'ah telah mengadopsi konsep 'denda' terhadap mereka yang tidak melunasi hutang tepat waktu, khususnya jika debitur mampu melunasinya. ${ }^{28}$

Pada BMT Dana Insani, apabila anggota melakukan keterlambatan pembayaran angsuran dengan sengaja maka akan dikenakan sanksi berupa biaya operasional sebesar $1 / 1000$ dari total pembiayaan. Dana ini kemudian akan dimasukkan ke dalam dana ZIS. ${ }^{29}$

Sedangkan di BMT Amratani Sejahtera apabila akad perjanjian telah jatuh tempo namun anggota belum melunasi kewajibannya, maka anggota harus membayar biaya administrasi penagihan dan biaya ganti rugi kepada BMT. ${ }^{30}$ Biaya administrasi penagihan dan biaya ganti rugi ini besarnya ditentukan berdasarkan kesepakatan di awal antara anggota dan BMT. Dana yang merupakan denda tersebut akan dimasukkan ke dalam dana baitul maal. ${ }^{31}$

Sementara itu di BMT BIF Nitikan apabila anggota menunggak pembayaran sebanyak tiga kali secara berturut-turut maka akan dikenakan sanksi berupa denda 3\% kali saldo pokok pembiayaan dan denda tersebut dimasukkan ke dalam dana sosial (pihak BMT melakukan pendebetan terhadap rekening tabungan anggota tersebut).

\section{F. Penghitungan Margin}

Penentuan besarnya margin pembiayaan murabahah di BMT Dana Insani dipengaruhi oleh besarnya pembiayaan dan jangka waktu pembiayaan. Jangka waktu pembiayaan ini berpengaruh pada biaya operasional. Besarnya biaya operasional ini minimal sebesar $2 \%$ dari besarnya pembiayaan. Jadi supaya tidak rugi, penentuan margin di BMT Dana Insani harus lebih besar

${ }^{27}$ Al-Qur'an 2:280.

${ }^{28}$ Muhammad. (2005), Manajemen Pembiayaan Bank Syariah, (Yogyakarta : UPP AMP YKPN), hal.133.

${ }^{29}$ Wawancara dengan Yuli Istianto (manajer BMT Dana Insani) pada 11 Mei 2007, melalui telepon.

${ }^{30}$ BMT Amratani (tt), Akad Pembiayaan Murabahah, (tidak dipublikasikan).

${ }^{31}$ Wawancara dengan Eni Arvianti (Manajer Dept. PSDM BMT Amratani) pada 8 Mei 2007, melalui telepon. 
dari biaya operasional. ${ }^{32}$ Sementara itu di BMT Amratani Sejahtera, penentuan besarnya margin pembiayaan murabahah dipengaruhi oleh harga barang, proyeksi pendapatan per bulan, jangka waktu, dan uang muka / urbun. Margin yang diharapkan oleh pihak BMT adalah sebesar 20.000,- s/d 25.000 / 1 juta (2-2,5\% per 1 juta) dari suatu pembiayaan. ${ }^{33}$ Sedangkan di BMT BIF Nitikan, penentuan besarnya margin pembiayaan murabahah dipengaruhi oleh besarnya biaya operasional (supaya tidak rugi, penentuan margin di BMT BIF Nitikan harus lebih besar dari biaya operasionalnya), harga tawar margin, laba/pendapatan anggota, kelancaran usaha anggota, jangka waktu, dan besarnya pembiayaan. Margin yang diterapkan di BMT BIF Nitikan berkisar antara 2,5-3\%. ${ }^{34}$

Jual beli boleh dilangsungkan dengan menggunakan harga waktu itu, dan boleh juga dengan harga ditangguhkan, demikian juga sebagian langsung sedang sebagian lagi ditangguhkan jika ada kesepakatan dari dua belah pihak. Pada BMT Dana Insani, BMT Amratani Sejahtera dan BMT BIF Nitikan penghitungan marginnya dipengaruhi oleh jangka waktu pembiayaan. Sesuai dengan uraian di atas, hal ini bukan merupakan sesuatu hal yang dilarang.

\section{Penutup}

Berdasarkan pembahasan pada bab sebelumnya, penelitian ini dapat disimpulkan sebagai berikut :

A. Praktek pembiayaan murabahah pada BMT digunakan untuk pembelian barang konsumsi maupun barang dagangan (pembiayaan tambah modal) yang pembayarannya dapat dilakukan secara tangguh (jatuh tempo / angsuran).

B. Risiko yang pernah dialami ke tiga BMT dalam pelaksanaan pembiayaan murabahah adalah :

1. BMT Dana insani dan BMT BIF Nitikan mengalami risiko penyalahgunaan dana oleh anggota, sedangkan BMT Amratani Sejahtera mengalami risiko tidak dapat membelikan barang yang dibutuhkan anggota.

2. BMT Dana Insani dan BMT BIF Nitikan belum pernah mengalami risiko yang terkait dengan obyek yaitu karena pembelian barang diwakilkan kepada anggota. Sedangkan pada BMT Amratani Sejahtera, tidak dapat membelikan barang yang dibutuhkan anggota jika barangnya tidak spesifik sehingga harus mewakilkan pembelian tersebut kepada anggota.

3. Ketiga BMT pernah mengalami risiko pembayaran yang kurang lancar dari anggota.

${ }^{32}$ Wawancara dengan Yuli Istianto, Op cit.

${ }^{33}$ Wawancara dengan Eni Arvianti, Op cit pada 20 Februari 2007.

${ }^{34}$ Wawancara dengan Supriyadi, Op cit. 
4. BMT Dana Insani belum pernah mengalami risiko yang terkait dengan anggota, sedangkan BMT Amratani Sejahtera pernah mengalami risiko penundaan pembiayaan. Sementara itu BMT BIF Nitikan pernah mengalami risiko pembatalan akad.

C. Ketiga BMT memiliki cara sendiri-sendiri dalam mengelola risiko murabahah, yaitu :

1. Untuk mengelola risiko yang terkait dengan barang, BMT Dana Insani dan BMT BIF Nitikan mewakilkan kepada anggota untuk membeli barangnya sendiri. Sementara itu, untuk menghindari risiko pembatalan pembelian barang karena adanya kerusakan / cacat pada barang, BMT Amratani Sejahtera akan memberikan diskon (mengurangi margin) kepada anggota supaya anggota tetap jadi membeli barang tersebut.

2. Untuk mengelola risiko yang terkait dengan pembayaran, ketiga BMT mensyaratkan adanya barang jaminan.

3. Untuk mengelola risiko yang terkait dengan anggota, BMT BIF Nitikan dan BMT Amratani Sejahtera mensyaratkan adanya uang muka.

D. Berdasarkan analisis yang telah dilaksanakan, terlihat bahwa sebagian besar konsep dan pelaksanaan pembiayaan murabahah pada ketiga BMT telah sesuai dengan prinsip-prinsip syariah, namun hal-hal yang dinilai belum memenuhi persyaratan akad murabahah yaitu dalam hal :

1. Penentuan akad.

BMT Dana Insani dan BMT BIF Nitikan menggunakan akad murabahah untuk pembiayaan tambah modal, padahal dalam perdagangan umumnya ada perputaran dana sehingga BMT dan anggota dapat berbagi hasil / keuntungan. Sedangkan pada BMT Amratani Sejahtera, pembiayaan tambah modal dilayani dengan akad musyarakah.

2. Pembelian barang.

Pada BMT Dana Insani dan BMT BIF Nitikan, pembelian obyek atau barang murabahah dilakukan dengan cara mewakilkan kepada anggota, sedangkan pada BMT Amratani Sejahtera pembelian barangnya diusahakan oleh pihak BMT.

Adapun saran-saran yang dapat penulis sampaikan adalah:

A. Pihak BMT dapat menggunakan akad bagi hasil jika anggota mengajukan pembiayaan tambah modal.

B. Pembelian obyek murabahah sebaiknya dilakukan oleh pihak BMT, namun apabila pembelian diwakilkan kepada anggota maka harus ada klausul wakalah dan akad murabahah baru dilakukan setelah barang tersebut menjadi milik pihak BMT.

C. Risiko-risiko yang terkait dengan murabahah seharusnya diantisipasi lebih awal walaupun selama ini BMT belum pernah mengalaminya. 
Asmi Nur Siwi Kusmiyati: Risiko Akad ...

\section{DAFTAR PUSTAKA}

M.Syafi'i Antonio (2001). Bank Syariah dari Teori ke Praktik. Jakarta: Gema Insani.

BMT BIF Group (tt), Sistem \& Prosedur Pembiayaan (tidak dipublikasikan).

Adiwarman Karim (2003). Bank Islam Analisis Fiqih dan Keuangan. Jakarta : IIIT Indonesia.

Majelis Ulama Indonesia (2003). Himpunan Fatwa Dewan Syariah Nasional, edisi kedua. Jakarta : MUI

Muhammad (2005). Manajemen Pembiayaan Bank Syariah. Yogyakarta : UPP AMP YKPN.

Sabiq, Sayyid (1988). Fikih Sunnah 12. Bandung : PT. Al-Ma'Arif.

Saeed, Abdullah (2004). Islamic Banking and Interest A Study of The Prohibition of Riba and its Contemporary Interpretation. Muhammad Ufuqul Mubin, dkk. (terj.). Bank Islam dan Bunga Studi Kritis Larangan Riba dan Interpretasi Kontemporer. Yogyakarta : Pustaka Pelajar.

Sumiyanto (2004). "Problem Transaksi Model Mudarabah dalam Lembaga Keuangan Syariah Studi Kasus LKS BMT-BMT di Yogjakarta", Tesis MSI UII (tidak dipublikasikan).

http : //www.accountancy.com.pk/docs/islam murabahah.pdf, diakses pada 9 April 2007.

Wiroso (2005). Jual Beli Murabahah. Yogyakarta : UII Press.

http://www.mui.or.id/mui in/product 2/fatwa.php?id=20 diakses pada 15 April 2007.

http://www.mui.or.id/mui_in/product_2/fatwa.php?id=24 diakses pada 15 April 2007.

\section{Sumber wawancara :}

Wawancara dengan Eddy Nofianto (Manajer Pusat Koperasi Syariah (PUSKOPSYAH)) pada 8 Januari 2007, di kantor BMT MITRA NUGRAHA DIY.

Wawancara dengan Yuli Istianto (manajer BMT Dana Insani) pada 9\&26 Februari 2007, di kantor BMT Dana Insani DIY.

Wawancara dengan Eni Arvianti (Manajer Dept. PSDM BMT Amratani) pada 20 Februari 2007, di kantor BMT Amratani Utama DIY.

Wawancara dengan Supriyadi (manajer BMT BIF Nitikan) pada 9 Februari 2007, di kantor BMT BIF Nitikan DIY.

Wawancara dengan Tri Martiwi (Bagian Pembiayaan BMT Dana Insani) pada 18 April 2007, di kantor BMT Dana Insani DIY. 